Chulieieva 0.,
Zolotaryov v.

\title{
REGULATION OF ELECTROPHYSICAL PROPERTIES OF FIREPROOF POLYMER COMPOSITIONS FILLED WITH HYDROMAGNESITE FOR CABLE PRODUCTS
}

\begin{abstract}
Рівень електрофізичних властивостей пожежобезпечних полімерних композицій в залежності від впливу інгредієнтів недостатньо досліджено. Особливо це стосується впливу модифікатора на властивості ізоляції та оболонки кабельної продукції. Тому об'єктом дослідження є електрофізичні властивості пожежобезпечних композиційних матеріалів кополімеру етилену з вінілацетатом, наповнених гідромагнезитом. Досліджували композицї кополімеру з показником плинності розплаву 2,5 та 5 г/10 хв, гідромагнезиту з середнім медіаннім діаметром часточок 1,4 мкм, аміносилани з динамічною в'язкістю 2 МПа·с та 2,5 МПа·с. Використовували апарат випробування ізоляціі, вимірювач електричного опору ізоляцї, міст змінного струму. Отримано електрофізичні характеристики, які дозволяють визначити склад, що забезпечує оптимальні значення для ізолящійних матеріалів і матеріалів оболонок кабельної продукцї з підвищеними вимогами пожежної безпеки. Використано методи електрофізичних досліджень з метою визначення впливу властивостей інгредієнтів полімерних композицій на електричну мічність, питомий об'ємний електричний опір, тангенс кута діелектричних втрат, діелектричну проникність. Електрична міцність підвищується під час використання полімерної матриці КЕВ-1 та модифікатору 1 від 21 до 40 кB/мм; під час використання полімерної матриці КЕВ-2 та модифікатору 2 від 22,5 до 42 кB/мм. Питомий об'ємний електричний опір значно підвищується для полімерних композищій, наповнених гідромагнезитом, при використанні полімерної матриці КЕВ-1 та модифікатору 1. Значення його збільшуються від 1·10 13 до 6,6 $10^{14}$ Ом·см. Використання в якості полімерної матриці КЕВ-1 призводить до зниження діелектричної проникності. Значне зниження цього показника від 4,1 до 3,6 спостерігається при використанні модифікатору 1 м меншою динамічною в'язкістю (2 МПа·с). Тангенс кута діелектричних втрат також знижується від 0,013 до 0,0046 при використанні модифікатору 1. Результати досліджень доцільно використовувати для розробки складу пожежобезпечних полімерних композищій для кабельної продукщіі.
\end{abstract}

Ключові слова: композиційні матеріали, кополімер етилену з вінілацетатом, електрофізичні властивості пожежобезпечних полімерних композицій.

\section{Introduction}

The development of industrial production of fireproof cables requires the use of polymer compositions with high electrophysical characteristics [1,2]. In order to reduce the flammability of fireproof compositions, inorganic filler-flame retardants are used [3-5]. The effect of fillers-flame retardant on the properties of polymer compositions is shown in $[6,7]$. The effect of modifiers on the improvement of the physicmechanical and rheological properties of polymer compositions is studied [8,9]. The properties of polymer compositions depend on their composition. The level of electrophysical properties of fireproof polymer compositions, depending on the influence of ingredients, has not been sufficiently studied. This is especially true of the effect of the modifier on the properties of the insulation and sheath of cable products. Therefore, the object of study is the electrophysical properties of fireproof composite materials: ethylene-vinyl acetate copolymer, filled with hydromagnesite. The aim of research is studying the effect of physicochemical properties and the concentration of modifiers and polymer matrix on the electrical and physical properties of fireproof composite materials: ethylene-vinyl acetate copolymer filled with hydromagnesite. This will allow a reasonable approach to determining the type of polymer and modifier. It also allows to quickly adjust the formulation of the composition, depending on the available raw materials or the desired electrical properties of the final product.

\section{Methods of research}

Ethylene-vinyl acetate copolymers EVA-1 with a melt flow index of $2.5 \mathrm{~g} / 10 \mathrm{~min}$ and EVA-2 with a melt flow index of $5.0 \mathrm{~g} / 10 \mathrm{~min}$ are investigated, as well as hydromag-nesite with an average particle diameter of 1.4 microns; modi-fier 1 aminosilane with a dynamic viscosity of $2.0 \mathrm{mPa} \cdot \mathrm{s}$ and modifier 2 - aminosilane with a dynamic viscosity of $2.5 \mathrm{mPa} \cdot \mathrm{s}$.

The methods that are used in the process of studying the electrophysical properties of fireproof polymer compositions are given in [10].

\section{Research results and discussion}

Measurement of the electrical strength of polymer compositions is carried out with an alternating voltage up to $50 \mathrm{kV}$ at a frequency of $50 \mathrm{~Hz}$. The research results are shown in Fig. 1, 2. The study of the dependences of the electrical strength indices of polymer compositions on the physicochemical properties of the polymer matrix, modifiers and hydromagnesite (fire retardant 5) demonstrates the effect of each of them on its value. 


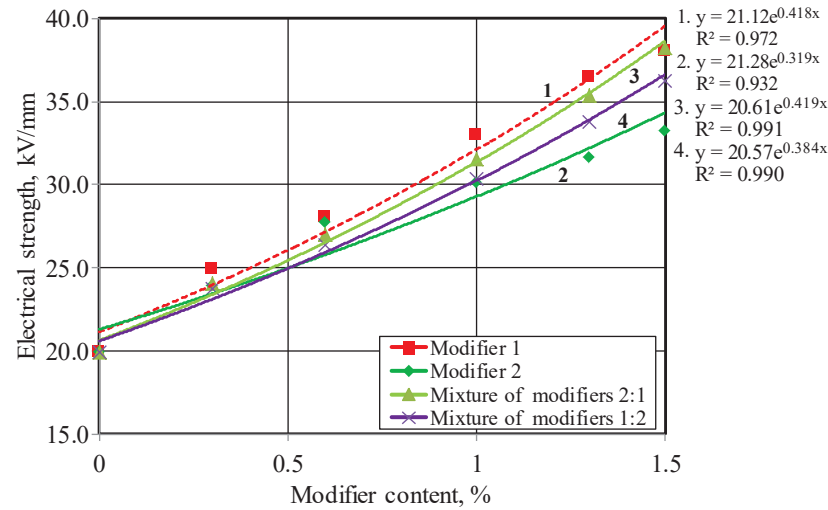

Fig. 1. The dependence of the electrical strength on the modifier content for polymer compositions based on EVA-1 and flame retardant 5 : 1 - modifier $1 ; 2$ - modifier 2; 3 - a mixture of modifiers, where $k 1=0.67 ; k 2=0.33 ; 4-$ a mixture of modifiers, where $k 1=0.33 ; k 2=0.67$

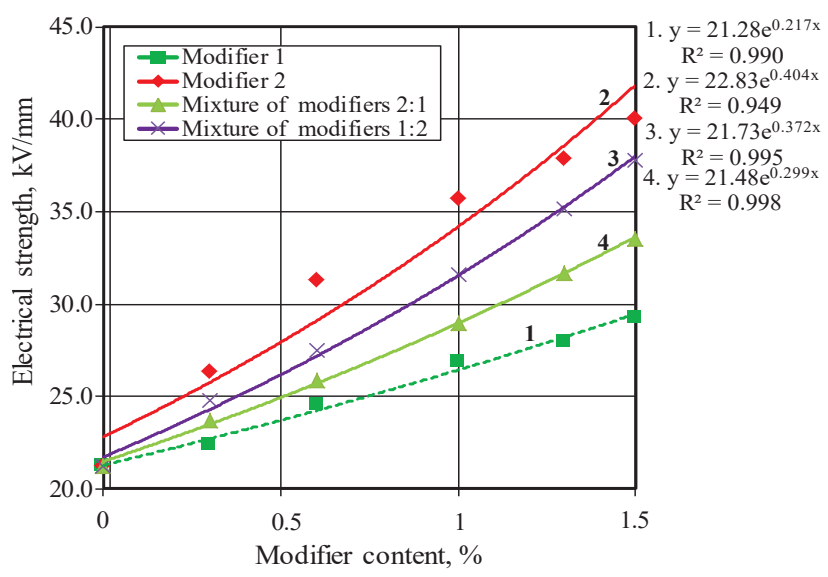

Fig. 2. The dependence of the electrical strength on the modifier content for polymer compositions based on EVA-2 and flame retardant 5: 1 - modifier $1 ; 2$ - modifier 2; 3 - a mixture of modifiers, where $k 1=0.67 ; k 2=0.33 ; 4-$ a mixture of modifiers, where $k 1=0.33 ; k 2=0.67$

Analysis of the results shows that the dielectric strength of the filled with hydromagnesite and modified polymer compositions increases. When using the polymer matrix EVA-1 and modifier 1 from 21 to $40 \mathrm{kV} / \mathrm{mm}$. When using the polymer matrix EVA-2 and the modifier - from 22.5 to $42 \mathrm{kV} / \mathrm{mm}$. That is, a significant increase in this indicator is observed when using a polymer matrix with a high melt flow index (5 g/10 min) and a modifier with a higher dynamic viscosity (2.5 $\mathrm{MPa} \cdot \mathrm{s})$.

To account for the contribution of each modifier, let's compile a regression equation for modifiers 1 and 2 :

$$
\begin{aligned}
& y=\left(21.12 e^{0.418 x}\right) \cdot k 1+\left(21.28 e^{0.319 x}\right) \cdot k 2 \\
& y=\left(21.28 e^{0.217 x}\right) \cdot k 1+\left(22.83 e^{0.404 x}\right) \cdot k 2,
\end{aligned}
$$

where $k 1$ - the number of modifier 1 in weight parts; $k 2-$ the number of modifier 2 in weight parts.

By changing the number of modifiers in their mixtures, the optimal values of the amount of the modified mixture are obtained (Fig. 1, curve 3, 4; Fig. 2, curve 3, 4).

The calculation of the specific volume electrical resistance is performed in the same way as in [10]. The research results are shown in Fig. 3.

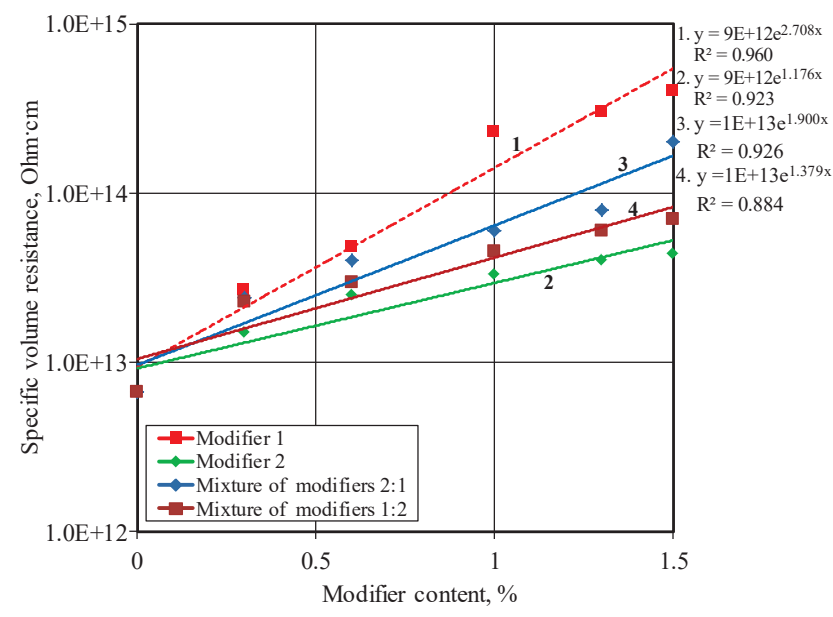

Fig. 3. The dependence of the specific volume resistance on the content of the modifier polymer compositions based on EVA-1 with a fire retardant 5 : 1 - modifier $1 ; 2$ - modifier 2; 3 - a mixture of modifiers, where $k 1=0.67 ; k 2=0.33 ; 4-$ a mixture of modifiers, where $k 1=0.33 ; k 2=0.67$

With an increase in the specific volume electrical resistance, the electrical insulating properties of the material are improved. The specific volume electrical resistance increases significantly for polymer compositions filled with hydromagnesite using the EVA-1 polymer matrix and modifier 1 . Its value increases from $1 \cdot 10^{13}$ to $6.6 \cdot 10^{14} \mathrm{Ohm} \cdot \mathrm{cm}$.

Regression equations taking into account the contributions of each of the modifiers in the mixture:

$$
y=\left(9 E+12 e^{2.708 x}\right) \cdot k 1+\left(9 E+12 e^{1.176 x}\right) \cdot k 2,
$$

where $k 1$ - the number of modifier 1 in weight parts; $k 2-$ the number of modifier 2 in weight parts.

Moisture has a particular effect on the change in specific volume electrical resistance, since polymer compositions filled with fire retardants have the ability to moisture permeability. The changes in the specific volume electrical resistance due to the moisture content of polymer compositions are investigated. The research results are shown in Fig. 4.

The decrease in the specific volume electrical resistance for polymer compositions is shown. Regression equations for mixture of modifiers:

$$
y=\left(4 E+17 e^{-39.9 x}\right) \cdot k 1+\left(1 E+17 e^{-25.5 x}\right) \cdot k 2,
$$

where $k 1$ - the number of modifier 1 in weight parts; $k 2-$ the number of modifier 2 in weight parts.

The measurement of the tangent of dielectric loss angle and electrical capacitance is carried out in the same manner as in [10]. The research results are shown in Fig. 5.

Regression equations taking into account the contributions of the mixture of modifiers 1 and 2 will be:

- for dielectric constant:

$y=\left(4.115 e^{0.011 x}\right) \cdot k 1+\left(4.089 e^{-0.02 x}\right) \cdot k 2$

- for the tangent of dielectric loss angle:

$$
y=\left(0.013 e^{-0.71 x}\right) k 1+\left(0.014 e^{-0.29 x}\right) \cdot k 2,
$$

where $k 1$ - the number of modifier 1 in weight parts; $k 2-$ the number of modifier 2 in weight parts. 


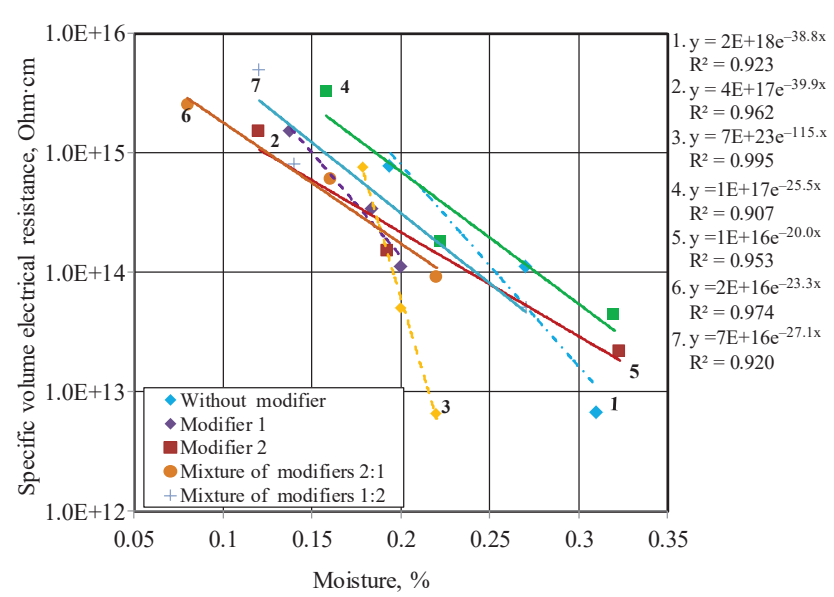

Fig. 4. Dependence of the specific volume electrical resistance on the moisture content of polymer compositions based on EVA-1 and flame retardant sample 5 and modifiers:

1 - without modifier; 2 - $0.6 \%$ modifier $1 ; 3-1.5 \%$ modifier 1 ;

4 - $0.6 \%$ modifier 2; 5 - $1.5 \%$ modifier $2 ; 6$ - a mixture of modifiers, where $k 1=0.67 ; k 2=0.33 ; 7-$ a mixture of modifiers, where $k 1=0.33 ; k 2=0.67$

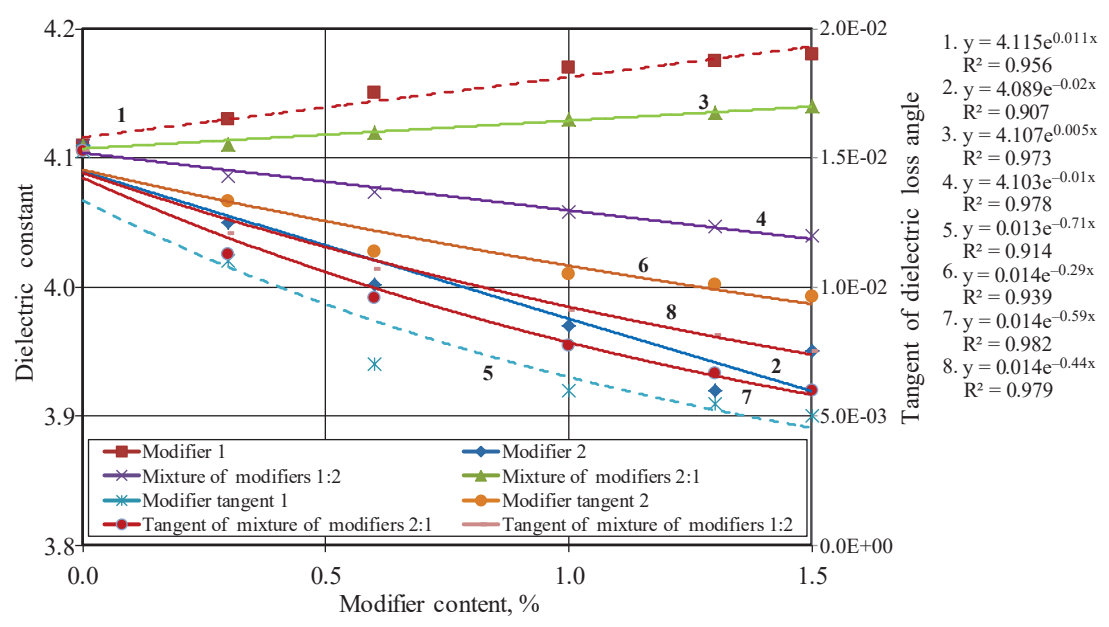

Fig. 5. Dependence of dielectric constant and angle tangent on the content of modifiers, for polymer compositions based on EVA-2 and flame retardant 5: 1, 5 - modifier 1; 2, 6 - modifier 2; 3, 7 - a mixture of modifiers, where $k 1=0.67 ; k 2=0.33 ; 4,8$ - a mixture of modifiers, where $k 1=0.33 ; k 2=0.67$

An important influence on the electrophysical properties of fireproof polymer compositions provides the formation of the supramolecular structure of the obtained compositions. This is evidenced by the results of studies of electrical strength, specific volume electrical resistance, dielectric constant and tangent of dielectric loss angle. The research results allow the development of technologies for the production of polymer compositions with controlled electrophysical properties for insulation and cable sheaths.

The advantages of this research are the study of the electrical properties of fireproof polymer composite materials using high-precision modern devices.

\section{Conclusions}

The study shows that the dielectric strength of the filled with hydromagnesite and modified polymer compositions increases. When using the polymer matrix EVA-1 and modifier 1 from 21 to $40 \mathrm{kV} / \mathrm{mm}$. When using the polymer matrix EVA-2 and modifier 2 from 22.5 to $42 \mathrm{kV} / \mathrm{mm}$. The specific volume electrical resistance increases significantly for polymer compositions filled with hydromagnesite when using the polymer matrix EVA-1 and modifier 1. Its value increases from $1 \cdot 10^{13}$ to $6.6 \cdot 10^{14} \mathrm{Ohm} \cdot \mathrm{cm}$. The use of EVA-1 as a polymer matrix leads to a decrease dielectric constant. A significant decrease in this indicator from 4.1 to 3.6 is observed when using modifier 1 with a lower dynamic viscosity (2 MPas). The tangent of dielectric loss angle decreases from 0.013 to 0.0046 when using modifier 1 with a dynamic viscosity of $2 \mathrm{MPa} \cdot \mathrm{s}$.

\section{References}

1. Mikhaylin Yu. A. Pokazateli ognestoykosti polimernykh materialov i metody ikh opredeleniya // Polimernye materialy. 2011 Issue 7. P. 26-31.

2. EN 50363-7:2005. Insulating, sheathing and covering materials for low voltage energy cables. Part 7: Halogen-free, thermoplastic insulating compounds. URL: https://shop.bsigroup.com/ ProductDetail $/$ ?pid $=000000000030065332$

3. Chuleeva E. V., Zolotarev V. M., Chuleev V. L. Napolnytelyantypyrenы. Teplofyzycheskye svoistva // Khimichna promyslovist Ukrainy. 2016. Issue 3-4 (134-135). P. 65-69.

4. Herbiet R. Mineral Flame Retardants: Market Outlook and Latest Developments // High Performance Filler. 2005. Issue 4. P. 20

5. Mechanical and fire retardant properties of EVA/clay/ATH nanocomposites - Effect of particle size and surface treatment of ATH filler / Cárdenas M. A., GarcíaLópez D., Gobernado-Mitre I., Merino J. C., Pastor J. M., Martínez J. de D. et. al. // Polymer Degradation and Stability. 2008. Vol. 93, Issue 11. P. 2032-2037. doi: http:// doi.org/10.1016/j.polymdegradstab.2008. 02.015

6. Thermal study of low-grade magnesium hydroxide used as fire retardant and in passive fire protection / Formosa J., Chimenos J. M., Lacasta A. M., Haurie L. // Thermochimica Acta. 2011. Vol. 515, Issue 1-2. P. 43-50. doi: http://doi.org/ $10.1016 /$ j.tca.2010.12.018

7. Flame retardancy and thermal stability of ethylene-vinyl acetate copolymer nanocomposites with alumina trihydrate and montmorillonite / Chang M.-K. Hwang S.-S., Liu S.-P. // Journal of Industrial and Engineering Chemistry. 2014 Vol. 20, Issue 4. P. 1596-1601. doi: http:// doi.org/10.1016/j.jiec.2013.08.004

8. Effect of Amino alcohol functionalized polyethylene as compatibilizer for LDPE/ EVA/clay/flame-retardant nanocomposites / Lujan-Acosta R., Sánchez-Valdes S., Ramírez-Vargas E., Ramos-DeValle L. F., EspinozaMartinez A. B., Rodriguez-Fernandez O. S. et. al. // Materials Chemistry and Physics. 2014. Vol. 146, Issue 3. P. 437-445. doi: http://doi.org/10.1016/j.matchemphys.2014.03.050

9. Chulieieva O. Development of directed regulation of rheological properties of fire retardant composite materials of ethylene vinyl acetate copolymer // Technology Audit and Production Reserves. 2017. Vol. 2, Issue 1 (40). P. 25-31. doi: http:// doi.org/10.15587/2312-8372.2018.129699

10. Chulieieva O., Zolotaryov V. Investigation of electrophysical properties of nanomodified fireproof eva polymer compositions // Technology audit and production reserves. 2019. Vol 1, Issue 1 (45) P. 31-38. doi: http://doi.org/10.15587/2312-8372.2019.157581

Chulieieva Olena, PhD, Director of Science and Technology Center, PJSC «uzhcable Works», Kharkiv, Ukraine, e-mail: echuleeva@ukr.net, ORCID: http://orcid.org/0000-0002-7310-0788

Zolotaryov Volodymyr, Doctor of Technical Sciences, Professor, General Director, PJSC «Yuzhcable Works», Kharkiv, Ukraine, e-mail: zavod@yuzhcable.com.ua, ORCID: http://orcid.org/0000-00023886-4993 